\title{
ISOLATION AND MOLECULAR CHARACTERIZATION OF FOOT AND MOUTH DISEASE VIRUS IN KAFRELSHEIKH GOVERNORATE, EGYPT 2014
}

\author{
Samy Kasem ${ }^{a}$, Asmaa Magouz ${ }^{a}$, EL-Bagoury G. Fekry, \\ Magdy Abdelatyc and Abeer Zaghlol ${ }^{a}$
}

${ }^{a}$ Department of Virology, Faculty of Veterinary Medicine, Kafrelsheikh University

${ }^{b}$ Department of Virology, Faculty of Veterinary Medicine, Banha University

${ }^{c}$ Veterinary Serum and Vaccine Research Institute, Abbasia, Cairo, Egypt

\section{ABSTRACT}

Foot and mouth disease virus (FMDV) is the most economically important veterinary pathogen due to its highly infectious nature and ability to cause persistent infection.In the period betweenAugust to October2014, an outbreak ofFoot and Mouth Disease (FMD) occurred in Egypt. This study was designated to isolate and detect the current strains of FMDV circulating in Egypt. Twenty sixtissue samples were collected from clinically diseased cattle and buffaloes from Kafrelsheikh province.The isolation of the causative agent wasdone by inoculation of baby mice intraperitoneally then passed to Baby Hamster Kidney-21 (BHK-21) cells. The inoculated mice showed paralysis and death, while the infected BHK-21 showed clear CPE (cell rounding and cell death). Molecular characterizations of the FMDV were doneusing universal primers followed by serotype specific primers for A, O,C and SAT2. Only serotypes SAT2 and A were detected with an overall detection rate of 53.8\%.Results of phylogenetic tree of the current FMDV strains revealed that there is no significant divergence among the recent isolated strains and other Egyptian isolated strains from different localities. 


\section{INTRODUCTION}

Foot and mouth disease (FMD) is an acute highly contagious and most fearful viral disease of 70 species of cloven hoofed animal (Carrillo et al., 2005). It is endemic in all Eastern Mediterranean countries including Egypt which constitutes a threat to other FMD free regions of the world (Kitching, 1990).FMD was recorded in Egypt since 1950 (Zahran, 1961) and over two hundred outbreak of FMD were recorded in 1989 in Turkey, Syria, Israel, Jordan and Saudi Arabia. In 1989, two large outbreaks occurred in Egypt and Libya (Mousa et al., 1984).

FMD infection characterized by a rapid febrile Illness with development of massive vesicular lesion in mouth including tongue, hard palate, dental pad, lips , gums, muzzle, coronary band, interdigital space and teats (Kitching, 2002).

The causative agent is a member of genus Aphthovirus, family Picornaviridae (Rueckert, 1996).Viralgenome consists of a linear single strandedpositive sense RNA of approximately 8.500 bases each surrounded by four structural proteins $\mathrm{VP}_{1}$ (1D), $\mathrm{VP}_{2}$ (1B), $\mathrm{VP}_{3}$ (1C) and $\mathrm{VP}_{4}$ (1A) to form a naked icosahedral nucleocapsid(Rueckert1996)and consist of 12 protein coding genes, in which the 1D gene ( encodes VP1), is the most surface exposed capsid protein and contains 3 important immunogenic site (Beck et al., 1983 and Nunez et al., 2006).

FMDV is recognized as seven distinct serotypes namely Serotypes A, O, C, Asia and South African territories "SAT serotypes" SAT1, SAT2 and SAT3which have been restricted in Africa. O, A, C are presented in Asia, Africa, South America and occasionally Europe (Knowles and Samuel 2003) and there are about 80 subtypes (Carrillo et al., 2005 and Bacharach, 
1968). Sequencing the region of FMDV genome encoding the capsid protein of virus provides the most detailed information about isolates, asthis region is variable between serotypes and subtypes (Domingo et al., 1990) .RT-PCR assays are alternative or complementary to the classical serological and viral isolation methods due to their high sensitivity and speed the fact that the handling of infectious viruses is not required (Saiz et al., 2003 and Le et al.,2012). Nucleotide sequencing was first used for the epidemiology of FMDV by (Beck and Strohmaier, 1987) who investigated the origin of an outbreak.

In this study we the isolation, molecular characterization and phylogenetic analysis of FMDV isolated from field samples collected from cattle and buffaloes in Kafrelsheikhprovinceduring the period from Augustto October 2014,were studied

\section{MATERIAL AND METHODS}

\subsection{Source and collection of samples:}

A total of 26 field samples (saliva, vesicular fluids and tongue epithelia) were collected from cattle and buffaloes suffering from typical FMD lesions (fever, ulceration on the interdigital space, mouth lesion with salivation, vesicles and ulceration on teat).Samples were collected from Kafrelsheikhprovince during the period fromAugust to October 2014. They were immediately transported on ice to the Central Diagnostic and Research Lab, Faculty of Veterinary Medicine KafrelsheikhUniversity and stored at -80 till used. Tongue epithelial specimens were homogenized in a proper volume of tissue culture medium with antibiotic, then clarified by centrifugation and filtrated via $0.22 \mu \mathrm{m}$ Millipore filter and also kept at $-80^{\circ} \mathrm{C}$ until used for inoculation (OIE Manual, 2009). 


\subsection{Virus Isolation:}

Isolation of FMDV was carried out on suckling mice and baby hamster kidney (BHK-21) cells. The samples of the clinically diseased animals were inoculated intraperitoneallyin baby mice. Thereafter, BHK-21 cells were inoculated with FMDV extracted from infected suckling mice. The BHK-21 cells were examined daily until pathognomonic cytopathic effects (CPE) were observed (OIE, 2000).

\subsection{RNA extraction:}

RNA was extracted from infected BHK-21 cells byTrizol Easy $\operatorname{Red}^{\mathrm{TM}}$ total RNA extraction kit (Intron Biotechnology) as per manufacture's protocol. Briefly, $500 \mu \mathrm{l}$ of infected BHK-21 cells suspensionswere mixed with $750 \mu$ of Trizol reagent followed by centrifugation at $10.000 \mathrm{rpm}$ for $10 \mathrm{~min}$. The supernatant was transferred to a fresh DEPC treated tube and added with $200 \mu \mathrm{l}$ of chilled chloroform. The mixture was left at room temperature for $15 \mathrm{~min}$ and centrifuged at $10.000 \mathrm{rpm}$ for $15 \mathrm{~min}$ at $4 \mathrm{C}$. The supernatant was discarded and the pellet was first washed with $100 \%$ followed by $70 \%$ ice-cold ethanol. Finally the pellet was re-suspended in $30 \mu \mathrm{l}$ RNAse free water and stored at $-80 \mathrm{C}$ for further analysis. Moreover, the extracted RNA was analyzed for its quality and quantity using Nano-drop method. Briefly, the equipment was first activated with $2 \mu \mathrm{l}$ of RNA/DNA free water. Later the same amount of sample was placed on the machine pedestal and the setting for RNA was selected. The system measures the quality and quantity of RNA in the given sample. 


\subsection{Reverse transcription of extracted RNA to cDNA:}

The reverse transcription (RT) of the extracted FMDV RNA to cDNA was performed using Maxime RT PreMix Kit (GeneON,TM GmbH, Germany) with oligo (dt) 18 primers. Briefly, a mixture of $5 \mu$ l of extracted RNA, $1 \mu$ l of oligodt and $2 \mu \mathrm{l}$ of sterile RNAs free water were prepared and incubated at $70^{\circ} \mathrm{C}$ for $10 \mathrm{~min}$, then placed or ice for $5 \mathrm{~min}$. Another mixture of $4 \mu \mathrm{l} 5$ reaction buffer, $1 \mu \mathrm{ldNTP} \operatorname{mix}(10 \mathrm{mM}$ of each $=40 \mathrm{mM})$ $1 \mu \mathrm{L}$ RNAs inhibitor, $1 \mu \mathrm{l}$ MMLVReverase $(200 \mathrm{U} / \mu \mathrm{l})$ and $13 \mu \mathrm{l}$ sterile RNAse free water. Mix I and Mix II were combined, gently vortexed and incubated in heat block at $55^{\circ} \mathrm{C}$ for $90 \mathrm{~min}$ then at $70^{\circ} \mathrm{C}$ for $10 \mathrm{~min}$ for inactivation of enzyme. cDNA was stored at $-20^{\circ} \mathrm{C}$ for further application.

\subsection{Primer designs:}

Five sets of oligonucleotide primers that specifically amplify FMDV serotypes were commercially synthesized by (Metabion international AG, Germany) and listed in table (1). The primers were aliquot to a final concentration of $50 \mathrm{pmol}$ and stored at -20C until used (Kandeil et al., 2013).

Table (1): Oligonucleotide primers used in amplification of FMDV (according to Kandeil et al., 2013)

\begin{tabular}{|c|c|c|c|}
\hline Primer name & "Oligonucleotide sequence & Region & Expected size \\
\hline $\begin{array}{c}\text { All serotypes } \\
\text { IF } \\
\text { IR }\end{array}$ & $\begin{array}{l}\text { GCC TGG TCT CAG GTC T } \\
\text { CCA GTC CCC TCC TCA GAT C }\end{array}$ & $\begin{array}{l}\text { 5UTR } \\
\text { 5UTR }\end{array}$ & 328bp \\
\hline $\begin{array}{c}\text { Serotype O } \\
\text { ARS4 } \\
\text { R-NK61 }\end{array}$ & $\begin{array}{l}\text { ACC AAC CTC CTT GAT GIG GCT } \\
\text { GAC ATG TCC TCCTGC ATC TG }\end{array}$ & $\begin{array}{l}\text { VP3 } \\
\text { 2B }\end{array}$ & 1301bp \\
\hline $\begin{array}{c}\text { Serotype A } \\
\text { A-1C562 } \\
\text { R-NK61 }\end{array}$ & 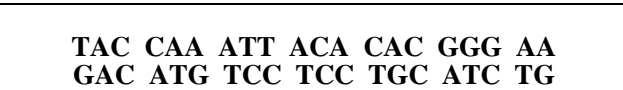 & $\begin{array}{l}\text { VP3 } \\
\text { 2B }\end{array}$ & 863-866bp \\
\hline $\begin{array}{c}\text { Serotype C } \\
\text { C-1C536 } \\
\text { R-NK61 } \\
\end{array}$ & $\begin{array}{l}\text { TAC AGG GAT GGG TCT GTG TGT ACC } \\
\text { GAC ATG TCC TCC TGC ATC TG }\end{array}$ & $\begin{array}{l}\text { VP3 } \\
\text { 2B }\end{array}$ & 877-833bp \\
\hline $\begin{array}{c}\text { SerotypeSAT2 } \\
\text { 1D20gf } \\
\text { 2B208R }\end{array}$ & $\begin{array}{c}\text { CCA CAT ACT ACT TTT GTG ACC TGGA } \\
\text { ACA GCG GCC ATG CAC GAC AG }\end{array}$ & $\begin{array}{l}\text { Vp1 } \\
\text { 2B }\end{array}$ & 715-730bp \\
\hline
\end{tabular}

Kafrelsheikh Vet. Med. J. Vol. 13 No. 2 (2015) 


\section{6. $\mathrm{PCR}$ reaction:}

It was performed in $50 \mu$ volume, in which the reaction mixture consisted of $10 \mu \mathrm{l}$ of $5 \mathrm{X}$ master mix (Tag/high yieldJena Bioscience, Jena, Germany) (5 X con. of thermostable DNA polymerase,dATP, dCTP, dGTP, dTTP, $\left(\mathrm{NH}_{4}\right) \mathrm{SO}_{4}, \mathrm{MgCl}$, tween 20, Noniodet P-40, stabilizers), $1 \mu \mathrm{l}$ of forward and reverse primers, $5 \mu \mathrm{l}$ of CDNA and $33 \mu \mathrm{l}$ of PCR grade water. The PCR were performed in Bio Rad T100 thermal cycler. Cycling protocol consisted of initial denaturation at $95^{\circ} \mathrm{C}$ for $5 \mathrm{~min}$ followed by 35 cycles of denaturation at $94^{\circ} \mathrm{C}$ for $30 \mathrm{sec}$, annealing at $52^{\circ} \mathrm{C} / 30 \mathrm{sec}$ and extension at $72^{\circ} \mathrm{C} / 90 \mathrm{sec}$ with final extension at $72^{\circ} \mathrm{C} / 10 \mathrm{~min}$. Throughout the development of the PCR, many modifications were applied to the annealing temperature, extension time and the number of cycles. Anegative control containing only PCR master mix, primers and PCR grade water was also included (Kandeil et al., 2013). PCR products were analyzed by agarose gel electrophoresis using $1.5 \%$ agarose. Amplified products were visualized by ulitraviolet light transillumination after staining with $0.5 \mu \mathrm{l} / \mathrm{ml}$ ethidium bromide. A 100 bp ladder (Gene ON, GmbH, Germany) was used as a molecular weight marker.

\subsection{Purification and Sequencing of PCR products:}

The PCR products of FMDV samples werepurified using Gene Jet PCR purification kits (Fermentas).The purified products were submitted for DNA sequencing and sequenced in both forward and reverse directions using the same amplification primers. The sequencing reaction was performed in an automated 
Isolation And Molecular Characterization Of Foot And ...

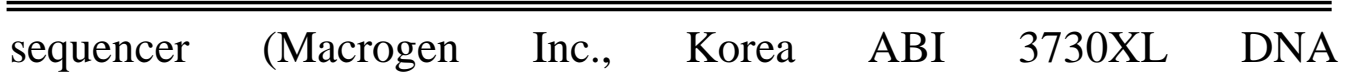
analyzer).Analysis of the sequence identity, divergence and phylogenetic relationship will be performed using the clustal $\mathrm{X}$ method with weighted residue table provided in the MEGA6 program (Tamura et al., 2013).

\section{RESULTS}

\subsection{Virus Isolation:}

FMDV was isolated by intraperitoneal inoculation of suckling mice and in BHK-21cells. Theinfected suckling mice showed paralysis ofhind limb and death (Fig. 1A). The infectedBHK-21 cells were used to isolate FMDV from collected samples; each treated sample was passaged 3 successive passages for propagation of FMDV which showed specific CPE which is characterized by rounding in cells, all samples gave rounding of the infected cell culture (Fig. 1C).

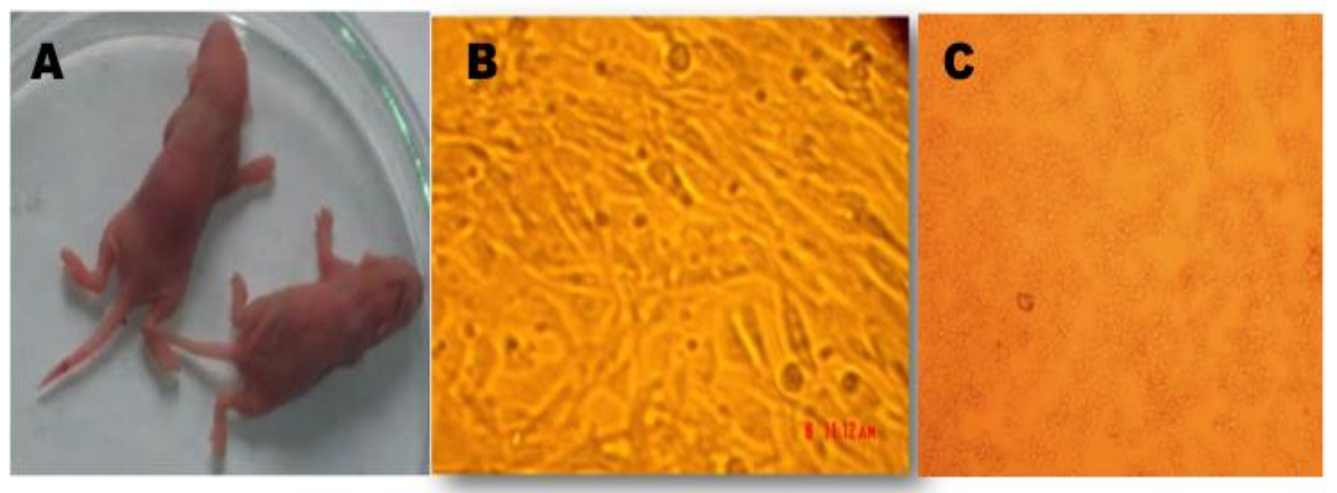

Fig. (1): Baby mice inoculated with FMD virus showing paralysis of the hind limbs (A). Normal BHK-21 cells (B) and BHK-21 cells inoculated with FMD virus suspected samples showing cell rounding $(\mathrm{C})$. 


\subsection{Identification and Subtyping of isolated viruses by PCR:}

Samples were obtained from symptomatic animals between August and October 2014 suffering from high fever, blisters inside the mouth, excessive salivation, blisters on the feet, vesicles in udder and teat, lameness, and decreased foot consumption. Of thetwenty six collected samples, fourteen samples (53.8\%) were positive for FMDV by PCR using the universal primers and by using serotype specific primers for A, SAT2, $\mathrm{O}$ and $\mathrm{C}$ on FMDV positive samples, results indicated that9 samples were SAT2 serotype and5 samples were A serotype. The amplification products were identified at the expected positions of $328 \mathrm{bp}$ for FMDV and 715-730 bp for SAT2 and 863-866bp for A serotype.

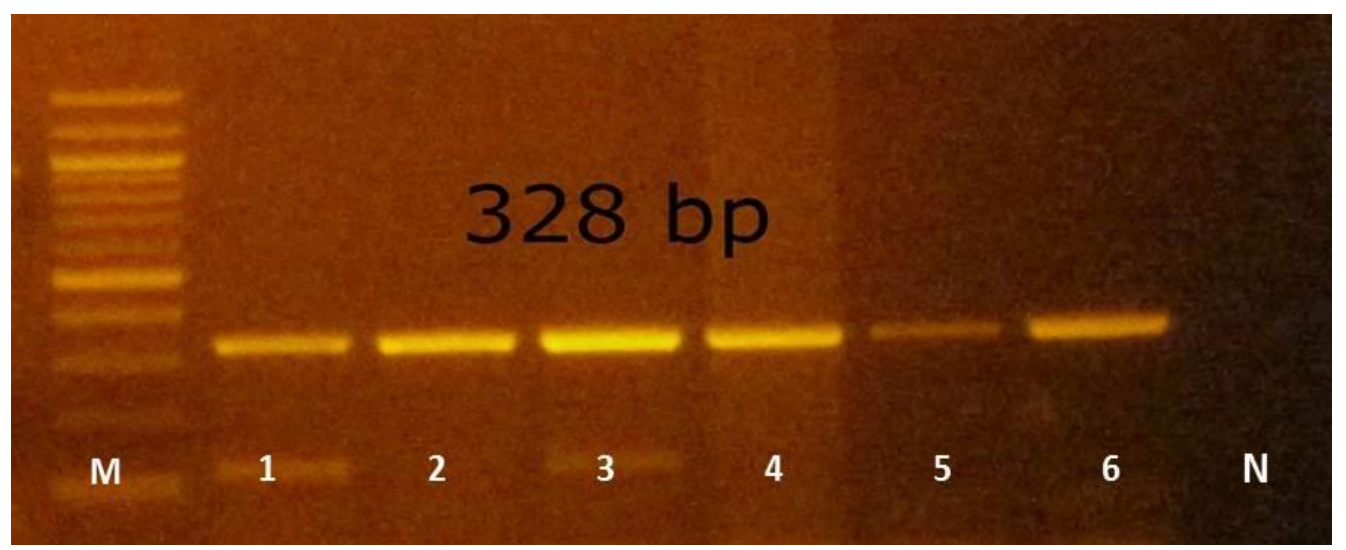

Fig. (2): Agarose gel electrophoresis of PCR amplified products utilizing FMDV universal primer $(1 \mathrm{~F}, 1 \mathrm{R})$ separated on $1,5 \%$ agarose gel and stained with ethidium bromide.Lane M; 100bp DNA size marker.Lane N; Negative control. Lanes 1, 2, 3, 4, 5, 6, showed positive amplification of $328 \mathrm{bp}$. 


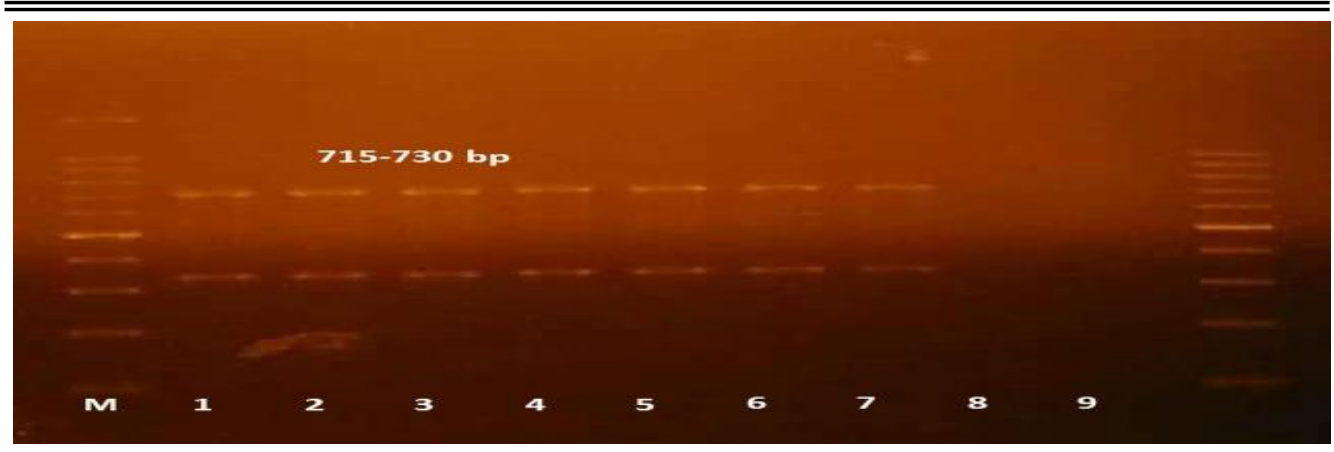

Fig. (3): Agarose gel electrophoresis of PCR amplified products utilizing FMDV serotype SAT2 specific primers separated on 1,5\% agarose gel and stained with ethidium bromide. Lane M; 100bp DNA size marker.Lanes 1, 2, 3, 4, 5, 6,7,8,9 showed positive amplification of 715-730 bp.

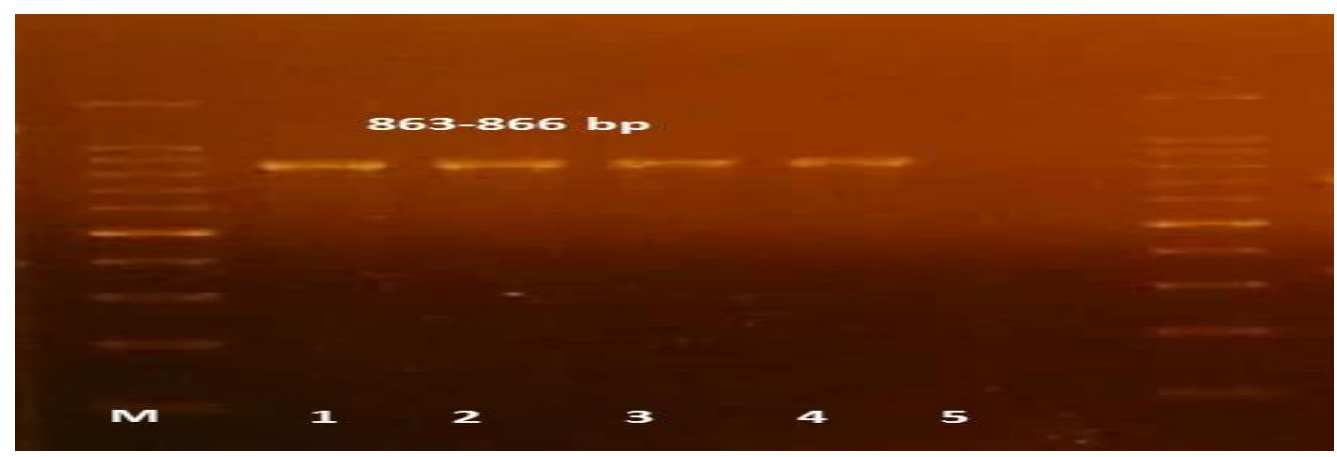

Fig. (4): Agarose gel electrophoresis of PCR amplified products utilizing FMDV serotype A specific primers separated on 1,5\% agarose gel and stained with ethidium bromide. Lane M; 100bp DNA size marker.Lanes 1, 2, 3, 4, 5 showed positive amplification of 863-866bp.

\subsection{Sequencing and Phylogenetic Analysis:}

Nucleotide Sequence analysis of VP2 coding-region of serotype A revealed that the recent isolated FMDV type A from Kafrelshiekh governorate, Egypt 2014 is closely related to type A isolate Egy/Al-Fayoum/2013 with $96 \%$ of identity (Fig. 5). 


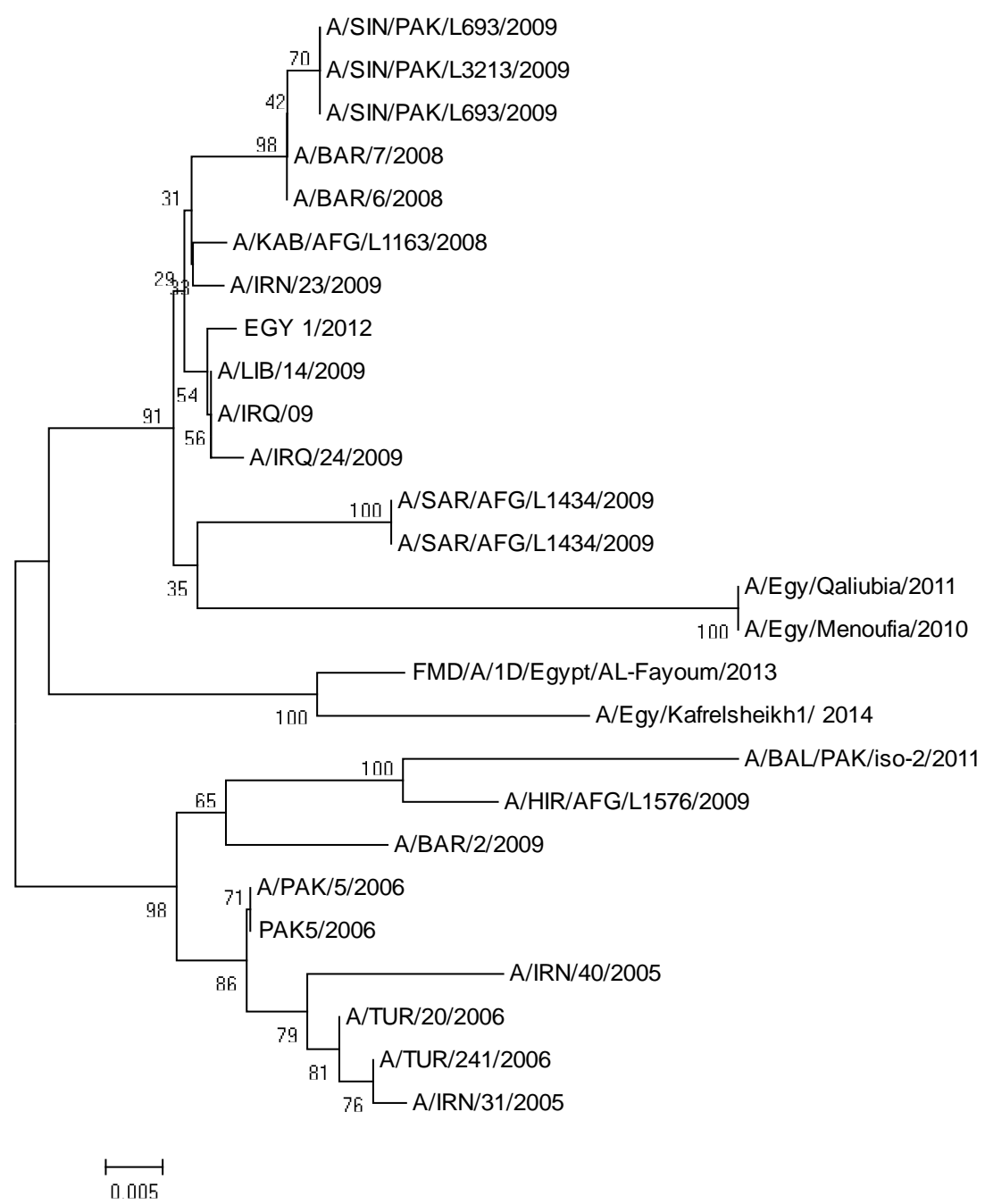

Fig. (5): The phylogenetic tree of FMDV strain A, The evolutionary relationship was inferred using the Neighbor-Joining method. The percentage of replicate trees in whichthe associated taxa clustered together in the bootstrap test (100 replicates) was shown next to the branches. The evolutionary distances were computed using the Kimura 2-parameter method (Kimura 1980). Evolutionary analyses were conducted in MEGA6. 
Nucleotide Sequence analysis of VP1 coding-region of serotype SAT2 revealed that the recent isolated FMDV type A from Kafrelshiekh governorate, Egypt 2014 is closely related to type SAT2 isolate EGY/23/2010 with $96 \%$ of identity (Fig. 6).

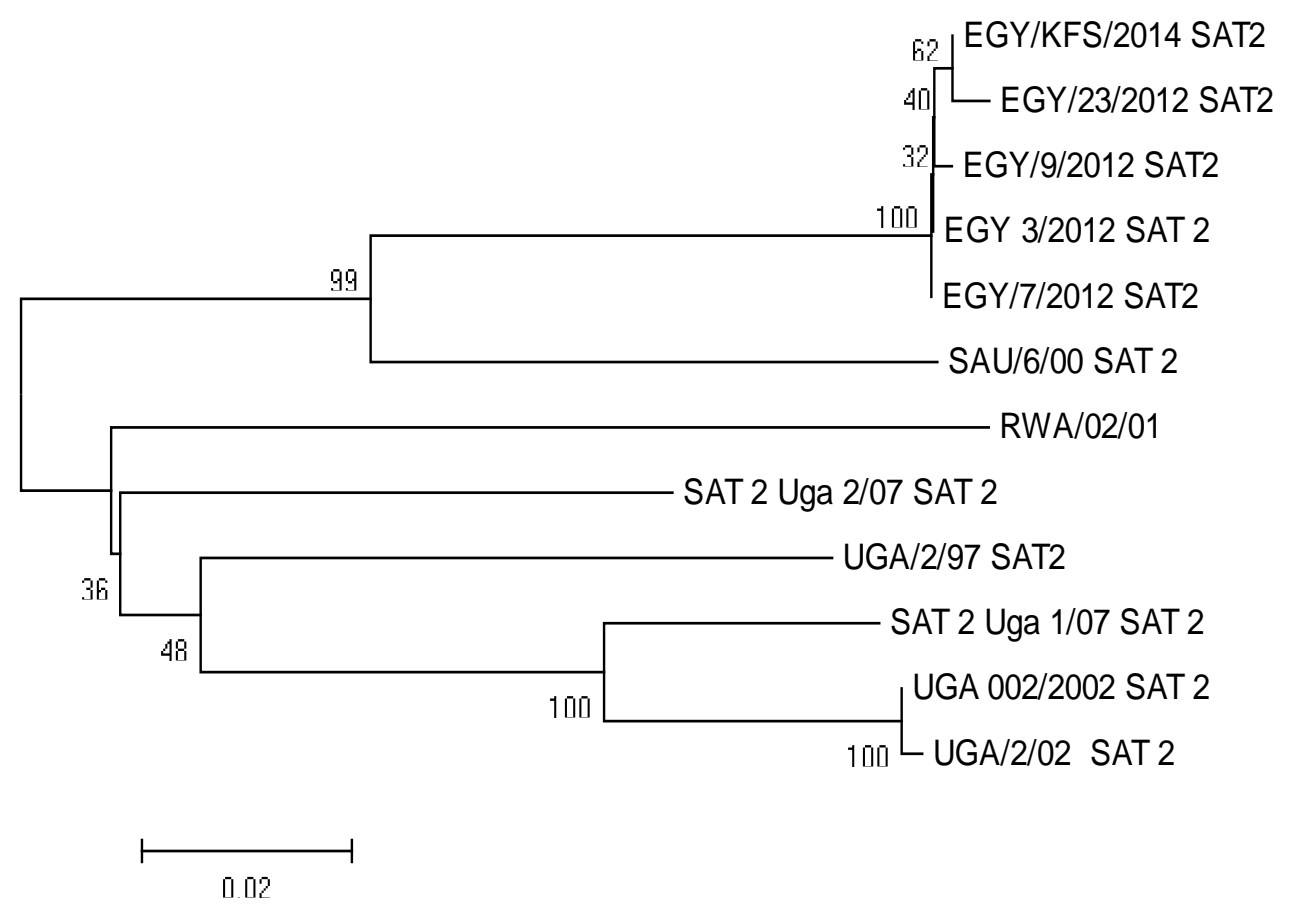

Fig. (6): The phylogenetic tree of FMDV strain SAT2, The evolutionary relationship was inferred using the Neighbor-Joining method. The percentage of replicate trees in which the associated taxa clustered together in the bootstrap test (100 replicates) was shown next to the branches .The evolutionary distances were computed using the Kimura 2parameter method( Kimura 1980). Evolutionary analyses were conducted in MEGA6. 


\section{DISCUSSION}

FMD is a highly contagious viral disease affecting cattle, pigs, sheep and other cloven hoofed animals including various wildlife species. Although most animals recover butFMD can has a devastating effect on agricultural production through lower growth rates, lower fertility and reduced milk production (Webb 2008). Early and specific diagnosis of FMDV represents an essential tool for the control of the disease (Knowles et al., 2001). Characterization of the FMDV serotype is essential for tracing the source of the virus with proper selection of the effective vaccine (Clavijo et al., 2004).

In the current study, the isolation of FMD viruses from cattle and buffaloes suffering from typical signs of FMD was described .The viruses were isolated from Kafrelsheikh provinces in the Northern part of Egypt through intraperitoneal inoculation of baby mice which showed paralysis and death (OIE, 2000). Also BHK-21 cells were used to isolate FMDV from collected samples; each treated sample was passaged 3 successive passages for propagation of FMDV which showed specific CPE which is characterized by rounding in cells (OIE, 2000), fourteen samples gave positive rounding in the cell culture.

Positive samples, which showed CPE in BHK-21, were tested by PCRassay. The data from this study showed that 14out of 26 samples (53.8\%) were confirmed as FMDV using universal primers $1 \mathrm{~F}$ and 1R.Positive samples were subsequentlysubtyped as SAT2 and A serotypes using serotype specific primers. The remaining FMDV negative samples may possibly contain FMD similar viruses as Vesicular stomatitis (VS). Only 5/14 (35.72\%) 
of the samples were identified as serotype A, while 9/14(64.28 \%) of the samples were positive for serotype SAT2.These results of serotyping A and SAT2 were in agreement with (Kandeil et al., 2013)who used the same primers in serotyping of isolates from six provinces across Egypt (Kafr el-Sheikh, Gharbya, Giza, BeniSuef, Asiut and Sohag).The relatively high detection rate in this study confirmed earlier studies which indicated that FMD is endemic in Egypt since 1950(Zahran, 1960, Mousa et al., 1984 and Kitching, 1990). The confirmation of the presence of SAT2serotype in our study is in accordance with El-Shehawy et al., 2014 and Kandeil et al., 2013 who reported a massive new FMD serotype SAT2 outbreak in in Egypt in February 2012. The evolution of the SAT2 serotype in Egypt, which is endemic for types $\mathrm{O}$ and $\mathrm{A}$, in February 2012 was a serious development in a region with an important livestock sector.The occurrence of FMD outbreak in Egypt starting fromFebruary was frequently related to importation of live animals specially from Sudan and Ethiopia, shortage of quarantine measures and the windy climatic conditions which hindered the government's efforts to control the outbreak(Lockhart et al., 2012and Kandeil et al., 2013).Our results also were in accordance with Amal et al., 2011who detected FMDV serotype A in Sharkia and Kafrelsheikh provinces by indirect sandwich ELISA in 8 samples out of 15 epithelial tissue samples from 90 infected animals, and also with Knowles et al. (2007) who described the characterization of FMD serotype A virus responsible for Egypt 2000 outbreak.AbdelRahman et al., 2006 and Farag et al., 2005 suggested that type A virus may have been introduced into Egypt through live animal importation. 
FMDV serotype $O$ couldn't be verified in this study which is in contrast with Moussa et al. (1979) who stated that type "O" virus was the most prevalent in setting the disease among infected cattle and buffaloes in Egypt during the last 25 years. We suggest thatserotype $\mathrm{O}$ may have been controlled by vaccination.

It could be recommended that the national policy should be directed toward animal protection against FMD must include serotype SAT2.These finding together with the endemic nature of the FMDV infection in Egypt make the routinely genetic characterization of FMV viruses circulating in Egypt important for screening the evolution of new serotypes. Addressing virus circulation is challenging and requires comprehensive set of measures, including the capacity to respond rapidly and effectively to incursions.

\section{REFERENCES}

- Amal, M.A.Raof ;Iman, Y. Haleem;Nawal, M. Aly; M.M. Garhy and GehaA. Hosny.(2011): Epidemiological Diagnosis of Foot and Mouth Disease among Cattle in Sharkia and Kafr El Sheikh Governorates. International Journal of Virology, 7: 191-197

- Abd El-Rahman, A.;Farag,M.; El-Kilany, S. and El-Yaeid, M. (2006): Isolation and identification of serotype $O$ of foot and mouth disease virus from imported bulls and its correlation to the current used vaccine strain. Proceedings of the 3rd International Conference on Veterinary Research Division in National Research Center, December 5-6, Egypt, : 91-100 
- Bacharach, H.L. (1968): Foot and mouth disease. Rev. Micro biol., 21: 201-244.

- Beck, E.; Feil; G. and Strohmaier, K. (1983): The molecular basis and antigenic variation of foot and mouth disease virus. EMBOH 2(4): 555-559.

- Beck, E. and Strohmaier, K. (1987): Subtyping of European FMDv strains by nucleotide sequence determination. J. Virol. 61: 1621-1629.

- Carrillo, C.; Tulman, E.R.; Delhon, G.; Lu, Z.; Carreno, A.; Vagnozzi, A.; Kutish, G.F. and Rock, D.L. (2005): Comparative genomic of FMDv. J.Virol., 10: 6487-6504.

- Clavijoa, A.; Zhoub, E.; Holea, K. and Galica, B. (2004): Development and use of a biotinylated $3 \mathrm{ABC}$ recombinant protein in a solid-phase competitive ELISA for the detection of antibodies against foot-and-mouth disease virus.J.Virol. Methods 120: (2) 217-227.

- Domingo, E.; Mateu, G.; Martinez, M.A.; Dopazo, J.; Moya, A. and Sobrino, F. (1990): Genetic variability and antigenic divesily of FMDv in E. Kustak, R.G. Marusyk, F.A.; Murphy and M.H.V. Van RegenMortel (Eds.) Applied Virology Research, Vol. 2, Plenum, New York, 233-259.

- Donald Webb (2008): The economic and social impact of the Institute for Animal Health ${ }^{\text {e }} \mathrm{s}$ work on Foot and Mouth Disease. Institute for AnimalHealth.Edinburgh. 
- El-Shehawy, L.I., Abu-Elnaga, H.I., Rizk, S.A., El-Kreem, A.S.A., Mohamed, A.A. and Fawzy, H.G., (2014): Molecular differentiation and phylogenetic analysis of the Egyptian foot-and-mouth disease virus SAT2. Archives of virology, 159, 437-443.

- Farag, M.A., A. Alsokayran, K.S. Mazloum and A.M. Al-Bokmy, (2005): The role of small ruminants in the epizootology of foot and mouth disease in Saudi Arabia with reference to the economic impact of the disease on sheep and goats. Vet.Med. J., 40: 23-41

- Kandeil, A.; EL Shesheny, R.; Kayali, G.; Moatasim, Y.; Bagato, O.; Darwish, M.; Gaffar, A.; Younes, A.; Farag, T.; Kutkat, M.A. and Ali, M.A. (2013). Characterization of the recent outbreak of foot and mouth disease virus serotype ST2 in Egypt. Arch Virol. 158, 619-627.

- Kitching, R.P.,( 1990): Foot and mouth disease in the Middle East and North Africa. Ann. AssistentVeternery Teachers, Researcher Workers, Scarborough, : 10-38.

- Kitching, R.P. (2002): Identification of foot- and Sub-clinically infected animals and differentiation from vaccinated animals. Rev. Sci. Tech. Off. Int. Epiz., 21(3): 531-538.

- Knowles, N.J.; Samuel, A.R, Davies, P.R, Kitching, R.P, Donaldson, A.I. (2001): Outbreak of FMDV serotypes O in the UK caused by a pandemic strain, Vet.Rec. 148:258-259.

- Knowles, N.J, Samuel, A.R. (2003): Molecular epidemiology of footand-mouth disease virus. Virus Res. 91:65-80. 
- Knowles, N., Wadsworth, J., Reid, S., Swabey, K., El-Kholy, A., Abd El-Rahman, A., Soliman, H., Ebert, K., Ferris, N., Hutchings, G., Statham, R., King, D., Paton, D. (2007): Foot - and - mouth disease viruses serotype A in Egypt. Emerg. Infect. Dis. 13(10): 1593-1596.

- Le, V.P.; Lee, K.N.; Nguyen, T.; Kim, Sim, S.M.; Cho, I.S.; Khang, D.D.; Hien, N.B.; Van Quyen, D. and Park, J.H. (2012): A rapid molecular strategy for early detection and characterization of Vietnamese foot and mouth disease serotypes O, A and A Sia I. K. Virol Methods, 180: 1-6.

- Lockhart, C, K., Sumption., Pinto, J. \&Lubroth, J. (2012): Foot-andmouth disease caused by serotype SAT2 in Egypt and Libya. EMPRESWatch,25.www.fao.org/docrep/015/an380e/an380e00.pdf.

- Moussa AAM, Daond A, Tawfik S, Omar A, Azab A, Hassan NA (1979). Susceptibility of water buffaloes to infection with foot-andmouth disease virus (FMDV). J Egypt Vet Med Assn.; 39:65-83.

- Moussa, A.A.M.; Daoud, A.M.; Hussein, K.; Hassan,N.A.; Fahmy, F.; Azab,A.M. and Lila El-Shehawy (1984): "Pr-evalence of FMD in Egypt." Agr. Res. Rev., 62 (5B): 55-58.

- Nunez, J.I. Fusi, P.; Borrego, B.; Brocchi.; E.; Pacciarini, M.L. and Sobrino, F . (2006): Genomic and antigenic characterization of viruses from the 1993 Italian foot and Mouth Disease Outbreak Arch Viol. 151. 127-142. 
- Rueckert, R. R.( 1996): Picornaviridae: the viruses and their replication, P.609-654. In B.N. Fields, D.M. Knipe, and P.H. Howley (ed.), Fields virology $3^{\text {rd }}$ ed. Lippincott-Raven, Philadelphia, Pa.

- Saiz, M.; De La Morena, D.B.; Blanco, E.; Nunez, J.L.' Fernandez, R.; Sanchez-Vizkaino, J.M. (2003): Detection of foot and mouth disease virus from culture and clinical samples by reverse transcription-PCR coupled to restriction enzyme and sequence analysis. Vet. Res. 34: 105-117.

- Zahran, G.E., (1960): Foot-and-mouth disease virus. II. Propagation and modification of 3 immunologic types of virus in embryonating chicken eggs. Am. J. Vet. Res., 22: 527-532.

- OIE (2009): Terrestrial Manual 2009 (5), Foot and mouth disease (Chapter 2.1.5.) (1-29) May 2009.

- OIE (2000): FMD, Chapter 2.1.1. In manual of Standard for Diagnostic Test and Vaccine, 4th ed., 2000, Paris, pp.77-92.

- Saitou N. and Nei M. (1987): The neighbor-joining method: A new method for reconstructing phylogenetic trees. Molecular Biology and Evolution 4:406-425.

- Felsenstein J. (1985): Confidence limits on phylogenies: An approach using the bootstrap. Evolution 39:783-791.

- Kimura M. (1980): A simple method for estimating evolutionary rate of base substitutions through comparative studies of nucleotide sequences. Journal of Molecular Evolution 16:111-120.

- Tamura K., Stecher G., Peterson D., Filipski A., and Kumar S. (2013): MEGA6: Molecular Evolutionary Genetics Analysis version 6.0. Molecular Biology and Evolution30: 2725-2729. 
التوصيف الجزيئى والتتابع النيكلوتيدى لفيروس الحمى القلاعية فى مصر 2014 سامى قاسم ، أسماء معجوز ، جبر الباجورى ، مجدى عبد العاطى ، عبير زغلول يعتبر مرض الحمى القلاعية من أخطر الأمراض وأكثر الأمراض إنتشاراً فى مصروالعالم وذلك لأنه يتسبب فى خسائر إقتصادية كبيرة نتيجة لسرعة إنتشاره وقدرته على أحداث عدوة كامنة لفترة طويلة ونقص فى الإنتاج ووفيات فى الحيوانات الصغيرة ، تهذف هذه الدراسة إلى إستخدام الكثف الجزيئى والتتابع النيكلوتيدى لتشخيص مرض الحمى القلاعية فى الحيوانات المصابة فى مصر (2014) . من خلال تجميع 26 عينة حلقية من محافظة كفر الثيخ حيث يتوقع إصابتها بمرض الحمى القلاعية تم تشخيص الفيروس فى كل العينات بإستخدام يؤادى عامة مكبرة لجين (5oUTR) بإستخدام تفاعل البلمرة المنسلسل المسبوق بالنسخ العكسى حيث أظهرت النتائج إيجايية 14عينـة من 26 عينة ، ولعمل تصنيف للفيروس المشخص بإستخدام نفس الاختيار ولكن بإستخدام بوادئ خاصة

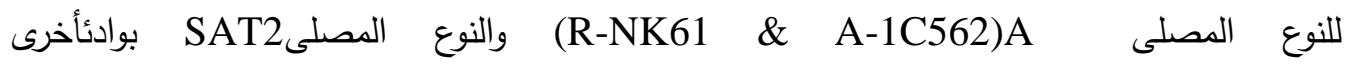
هى (1D209f \& 2B208R) والنوع المصلى Oبادئ هى (ARS4 K R-NK61) والنوع الدصلى Cبوادى وهى (C-1C536 K R-NK61) وجد إيجابية 6 عينات من 14عينة إيجابية مع البوادئ الخاصة بالنوع المصلى A و A عينات من النوع المصلى SAT وجد إيجابية العينات للنوع و وعدم وجود النوع المصلى C , O SAT لإِصابة بالمرض (53.8\%) 